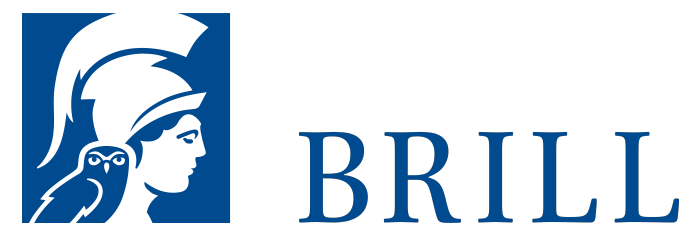

\title{
The Global Trajectories of Queerness
}

\author{
Re-thinking Same-Sex Politics in the Global South
}

Editors: Ashley Tellis and Sruti Bala

The Global Trajectories of Queerness interrogates the term "queer" by closely mapping what space the theorizing of samesex sexualities and sexual politics in the non-West inhabits. From theoretical discussions around the epistemologies of such conceptualizations of space in the Global South, to specific ethnographies of same-sex culture, this collection hopes to forge a way of tracking the histories of race, class, caste, gender, and sexual orientation that form what is called the moment of globalization. The volume, co-edited by Ashley Tellis and Sruti Bala, asks whether the societies of the Global South simply borrow and graft an internationalist (read Euro-US) language of LGBT/queer rights and identity politics, whether it is imposed on them or whether there is a productive negotiation of that language.

Contributing Authors: Sruti Bala, Laia Ribera Cañénguez, Soledad Cutuli, Roderick Ferguson, Iman Ganji, Krystal Ghisyawan, Josephine Ho, Neville Hoad, Victoria Keller, Haneen Maikey, Shad Naved, Guillermo Núñez Noriega, Stella Nyanzi, Witchayanee Ocha, Julieta Paredes, Mikki Stelder, Ashley Tellis, and Wei Tingting

Readership

All interested in queer politics in the context of globalization, theories and ethnographies of gender and sexuality, postcolonial literature, culture and politics

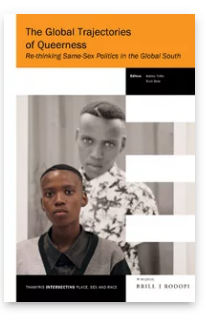

Pages: $271 \mathrm{pp}$. with ill.

Language:

English

Subjects:

Sociology \&

Anthropology,

Social Sciences,

Cultural Studies,

Social Sciences,

Gender Studies,

Social Sciences,

Global Studies,

Social Sciences,

Comparative

Studies \& World

Literature,

Literature and

Cultural Studies

Publisher: Brill

Series:

Thamyris/Intersecting:

Place, Sex and Race

Online, Volume: 30

Thamyris/Intersecting:

Place, Sex and Race,

Volume: $3^{\circ}$

E-Book (PDF)

Released online:

10 Jun 2016

ISBN: 978-90-

04-21794-2

MyBook

USD \$25.00 
Ashley Tellis, Ph.D. (1999), University of Cambridge, and 3o Oct 2015 postdoctoral Rockefeller fellow (2003-4) in LGBT Studies at the ISBN: $978-90-$ 04-30933-3 University of Arizona, Tucson, USA. He has taught at Universities in the US, UK and India and is currently Associate List price Professor in Gender, Writing and Research at The Banyan Academy of Leadership in Mental Health (BALM), Chennai, India.

Sruti Bala, Ph.D. (2007), University of Mainz/Germany, currently Assistant Professor in Theatre Studies at the University of Amsterdam, Netherlands and Research Fellow (2014-15) at the Interweaving Performance Cultures Research Center at the Freie Universität Berlin.

For more information see brill.com

Order information: Order online at brill.com +44330 3330049 | customerservices@brill.com Submission information: brill.com/authors

Titles published by Brill | Fink, Brill | mentis or Brill | Schöningh: +49(o)715413279216| brill@brocom.de 